\title{
Decavanadate interactions with actin: cysteine oxidation and vanadyl formation
}

\author{
Susana Ramos, ${ }^{a, c}$ Rui O. Duarte, ${ }^{c}$ José J. G. Moura ${ }^{c}$ and Manuel Aureliano*a,b \\ Received 2nd April 2009, Accepted 7th July 2009 \\ First published as an Advance Article on the web 5th August 2009 \\ DOI: 10.1039/b906255f
}

Incubation of actin with decavanadate induces cysteine oxidation and oxidovanadium(IV) formation. The studies were performed combining kinetic with spectroscopic (NMR and EPR) methodologies. Although decavanadate is converted to labile oxovanadates, the rate of deoligomerization can be very slow (half-life time of $5.4 \mathrm{~h}$, at $25^{\circ} \mathrm{C}$, with a first order kinetics), which effectively allows decavanadate to exist for some time under experimental conditions. It was observed that decavanadate inhibits F-actin-stimulated myosin ATPase activity with an $\mathrm{IC}_{50}$ of $0.8 \mu \mathrm{M} \mathrm{V} \mathrm{V}_{10}$ species, whereas $50 \mu \mathrm{M}$ of vanadate or oxidovanadium(IV) only inhibits enzyme activity up to $25 \%$. Moreover, from these three vanadium forms, only decavanadate induces the oxidation of the so called "fast" cysteines (or exposed cysteine, Cys-374) when the enzyme is in the polymerized and active form, F-actin, with an $\mathrm{IC}_{50}$ of $1 \mu \mathrm{M} \mathrm{V}_{10}$ species. Decavanadate exposition to $\mathrm{F}$ - and $\mathrm{G}$-actin (monomeric form) promotes vanadate reduction since a typical EPR oxidovanadium(IV) spectrum was observed. Upon observation that $\mathrm{V}_{10}$ reduces to oxidovanadium(IV), it is proposed that this cation interacts with G-actin $\left(K_{\mathrm{d}}\right.$ of $7.48 \pm$ $1.11 \mu \mathrm{M})$, and with $\mathrm{F}$-actin $\left(K_{\mathrm{d}}=43.05 \pm 5.34 \mu \mathrm{M}\right)$ with $1: 1$ and $4: 1$ stoichiometries, respectively, as observed by EPR upon protein titration with oxidovanadium(IV). The interaction of oxidovanadium(IV) with the protein may occur close to the ATP binding site of actin, eventually with lysine-336 and 3 water molecules.

\section{Introduction}

It has been recently reviewed that biological effects of vanadium are not exclusively due to monomeric vanadate or vanadyl (oxidovanadium(IV)) cation, but also to other oxovanadate forms such as decameric vanadate species. ${ }^{1}$ This oxovanadate species, also referred to as decavanadate $\left(\mathrm{V}_{10}\right)$, is known to affect lipidic structures, protein function and also several biochemical processes. ${ }^{2}$ One of these processes is the formation of F-actin, the major component of muscle thin filaments, is shown to be inhibited by decavanadate with an $\mathrm{IC}_{50}$ of $17 \mu \mathrm{M}$, whereas no effects were detected for monomeric vanadate species. ${ }^{3}$ These studies were further explored and the results described in the present paper.

The chemistry of vanadium is characterised by multiple oxidation states $(+2$ to +5$)$, being mostly found in the +4 and +5 states, both of which are readily accessible under physiological conditions. ${ }^{4}$ At low $\mathrm{pH}$ the V(IV) species (oxidovanadium(IV) cation) are more favored, whereas at high $\mathrm{pH} \mathrm{V}(\mathrm{V})$ (vanadate anions) is the most stable form of vanadium in aqueous solution. ${ }^{5}$ Around neutral $\mathrm{pH}, \mathrm{V}_{1}\left(\mathrm{H}_{2} \mathrm{VO}_{4}{ }^{-}\right.$and $\left.\mathrm{HVO}_{4}{ }^{2-}\right)$ condenses with itself to form dimeric $\left(\mathrm{V}_{2}\right)$, tetrameric $\left(\mathrm{V}_{4}\right)$ and pentameric $\left(\mathrm{V}_{5}\right)$ structures. ${ }^{6,7}$ Upon acidification of neutral solutions (from $\mathrm{pH} 2$ to 6) a decameric vanadate species $\left(\mathrm{V}_{10} \mathrm{O}_{28}{ }^{6-}\right)$ is formed. This vanadate species $\mathrm{V}_{10}$ is responsible for the yellow/orange colour of

${ }^{a}$ FCT, University of Algarve, Faro, Portugal. E-mail: maalves@ualg.pt; Fax: 351-289800066

${ }^{b}$ Centre for Marine Sciences (CCMAR), University of Algarve, Faro, Portugal

'REQUIMTE, Departamento de Química, Faculdade de Ciências e Tecnologia, FCT, Universidade Nova de Lisboa, 2829-516, Caparica, Portugal vanadate solutions and is thermodynamically unstable at neutral and alkaline $\mathrm{pH}$ values. This oxoanion contains three different types of vanadium atoms, the most unusual being the $\mathrm{VO}_{6}$ type observed for the two central vanadium atoms. ${ }^{5}$ Besides $\mathrm{pH}$, both vanadate concentration and ionic strength can also account for the different states of protonation and structures observed for the different oligomeric vanadate species that occur simultaneously in equilibrium..$^{7-9}$ The blue oxidovanadium(IV) cation $\left(\mathrm{VO}^{2+}\right)$ undergoes autoxidation to the colourless vanadate $\left(\mathrm{H}_{2} \mathrm{VO}_{4}^{-}\right)$in the presence of oxygen, whereas vanadate, in turn, can be reduced by reductants such as glutathione, ascorbate, $\mathrm{NADPH}^{10}$ or cysteine, ${ }^{11}$ whereas it has also been described that decavanadate reduction does not necessarily imply the disruption of the molecular structure. ${ }^{12}$

Oxidovanadium(IV) cation binds tightly to various proteins including serum albumin, carboxypeptidase, nucleases and phosphatases. ${ }^{4,13}$ Vanadate species associate randomly with proteins such as the E1E2-ATPases, ${ }^{1,14}$ phosphofructokinase, ${ }^{15}$ transferrin, ${ }^{16}$ ribonucleases ${ }^{1,17}$ among many others. ${ }^{1,4}$ Most studies about the interactions/effects of vanadate with proteins considered monomeric vanadate as the active species. ${ }^{1,4,8}$ However, in the last 10 years the number of studies involving decavanadate has increased gradually. ${ }^{1}$ In fact, $\mathrm{V}_{10}$ has proved itself to be a very useful tool in the comprehension of protein structure and function, biochemical mechanisms and biological processes, ${ }^{18-22}$ being now considered the major protein-bound vanadate species. ${ }^{1,22}$ Moreover, it is known that decavanadate interacts with enzymes at the polyphosphate, nucleotide and inositol-3-phosphate binding sites in the substrate domain or in an allosteric site, in a complex manner. ${ }^{1}$ 
The connection between vanadium and muscle contraction started when it was discovered that vanadium in horse-musclederived ATP inhibited sodium/potassium pump activity ${ }^{23}$ and since then many studies have been perfomed linking vanadium and vanadium complexes with proteins involved in the mechanism and regulation of muscle contraction. ${ }^{1,39,24}$ One of the major proteins of the contractile protein group is actin. Monomeric actin (G-actin) polymerizes to form F-actin, the major component of the thin filament of the contractile system. In muscle cells, this polymerization process is essential for contraction because G-actin, by itself, does not stimulate myosin ATPase activity. Previous studies from Combeau and Carlier ${ }^{25}$ demonstrate that vanadate, upon binding to F-actin-ADP subunits, increases the strength of actin-actin interactions in the filament in a phosphate-like fashion. It has been reported that vanadate stabilizes F-actin filaments through the formation of F-actin-ADP. $V_{1}$ complexes and induces actin polymerization by inhibiting specific tyrosine phosphatases. ${ }^{26}$ However, vanadate concentrations in the millimolar range favour the appearance of vanadate oligomers such as tetrameric vanadate species, and could induce changes in protein structure and function, and eventually destabilize the structure of the filament, which was also suggested by Ramos et al. ${ }^{3}$ These authors proposed that besides $\mathrm{V}_{4}$ species, the presence of $\mathrm{V}_{10}$ strongly induces $\mathrm{F}$-actin depolymerization and $\mathrm{G}$-actin polymerization inhibition, whereas no effects were observed for metavanadate solutions up to $2 \mathrm{mM}$, that contain mostly monomeric vanadate species but not $\mathrm{V}_{10}$ species. Moreover, it was also demonstrated that $\mathrm{V}_{10}$ becomes more stable upon interaction with G-actin. ${ }^{3}$

In the present paper, it was observed that only decameric species induce oxidation of cysteines from actin, probably through a process that involves the reduction of $\mathrm{V}_{10}$ to oxidovanadium(IV). It is proposed that this redox behaviour of $\mathrm{V}_{10}$ might be responsible, at least in part, for the described inhibition of the myosinS1-ATPase stimulated by F-actin exposured to decavanadate. Although it is not possible to determine which oxovanadate species or vanadium atoms undergo reduction, the effect is only observed in the presence of decavanadate.

\section{Material and methods}

\subsection{Protein purification}

Actin was extracted from acetone powder of rabbit skeletal muscle in a medium containing $2 \mathrm{mM}$ Tris, $\mathrm{pH} 8.0,0.2 \mathrm{mM}$ ATP, $0.2 \mathrm{mM} \mathrm{CaCl}_{2}, 0.5 \mathrm{mM} \beta$-mercaptoethanol, and $0.005 \% \mathrm{NaN}_{3}$, as described by Pardee and Spudich. ${ }^{27}$ G-actin (Mr $42.3 \mathrm{kDa}$ ) concentration was determined by measuring the absorbance at $290 \mathrm{~nm}$ using an extinction coefficient of $0.617 \mathrm{mg}^{-1} \mathrm{~mL} \mathrm{~cm}^{-1} .^{28}$ Myosin subfragment-1 (S1) was prepared from leg and dorsal rabbit skeletal muscle and obtained by chymotryptic digestion as indicated in Tiago et al. ${ }^{9} \mathrm{~S} 1\left(M_{\mathrm{r}} 115 \mathrm{kDa}\right)$ concentration was determined spectrophotometrically by using an extinction coefficient of $\varepsilon^{1 \%}{ }_{280}=7.5 \mathrm{~cm}^{-1}$.

\subsection{Preparation of "metavanadate", "decavanadate" and vanadyl solutions}

Metavanadate solutions ( $50 \mathrm{mM}, \mathrm{pH}$ 6.0-7.0) were prepared from ammonium metavanadate $\left(\mathrm{NH}_{4} \mathrm{VO}_{3}\right)$. Decavanadate solutions were obtained by adjusting the $\mathrm{pH}$ of the metavanadate solution to 4.0. ${ }^{14,29}$ The presence of decameric vanadate species was revealed by a characteristic orange color. Decavanadate solutions were always adjusted to $\mathrm{pH} 7.5$ immediately before using. Vanadyl solution $(50 \mathrm{mM})$ was obtained from vanadyl sulfate $\left(\mathrm{VOSO}_{4}\right)$ in anaerobic conditions using a glove box. Wherever possible, vanadium(IV) and (V) solutions were added to the assays from the concentrated or from a 10 -fold dilution of the stock solutions. All the solutions were kept at $4{ }^{\circ} \mathrm{C}$.

\subsection{UV-Visible characterization of decavanadate solutions}

The kinetics of decameric species dissociation was determined from measurements of the absorption at $400 \mathrm{~nm}$ (an absorption band which is characteristic of decameric vanadate), using a HP 8452A diode array spectrophotometer. The reactions were started after addition of $1 \mathrm{mM}$ decavanadate solution $(100 \mu \mathrm{M}$ of decameric vanadate species) to the reaction medium $(2 \mathrm{mM}$

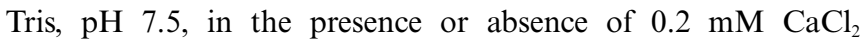
and $0.2 \mathrm{mM} \mathrm{ATP}$ ). The kinetics were followed for $120 \mathrm{~min}$ at different temperatures. Since the $\mathrm{V}_{10}$ dissociation follows a firstorder reaction kinetics, ${ }^{29}$ it was possible to determine the activation energy $\left(E_{\mathrm{a}}\right)$ for the dissociation.

\section{$2.3 \quad{ }^{51} \mathrm{~V}$ NMR measurements}

${ }^{51} \mathrm{~V}$ NMR spectroscopy measurements were performed on a Bruker AM-400 MHz spectrometer at 105.2 MHz equipped with a $5 \mathrm{~mm}$ multinuclear inverse probe. Spectra were acquired at $25^{\circ} \mathrm{C}$, using $0.5 \mathrm{ml}$ of samples containing $10 \% \mathrm{D}_{2} \mathrm{O}$, under the following conditions: $90^{\circ}$ pulse angle, spectral width $45454 \mathrm{~Hz}$, acquisition time $0.086 \mathrm{~s}$, number of transients between 12000 and 25000 and a relaxation delay of $0.01 \mathrm{~s}$. For comparative measurements all the spectral parameters were kept constant. ${ }^{51} \mathrm{~V} \mathrm{NMR}$ chemical shifts are reported relative to an external reference, $\mathrm{VOCl}_{3}(0 \mathrm{ppm})$. NMR spectra of metavanadate $(2 \mathrm{mM})$ and decavanadate $(5 \mathrm{mM})$ solutions were obtained in $2 \mathrm{mM}$ Tris ( $\mathrm{pH} 7.5$ ), $0.2 \mathrm{mM} \mathrm{CaCl}_{2}$, in the absence or presence of ATP and ADP (2 mM), G- and F-actin, as desired. The ionic strength effect was evaluated by $\mathrm{KCl}$ addition $(5 \mathrm{mM})$. The ${ }^{51} \mathrm{~V}$ NMR line widths of the several free and bound vanadate resonances represent the widths at halfheight after subtraction of $20 \mathrm{~Hz}$ used in line broadening. The concentrations of each vanadate species $V_{x}$ were calculated from the fractions of the total integrated areas using the following equation: $\left[V_{\mathrm{x}}\right]=\left(A_{\mathrm{x}} / A_{\mathrm{t}}\right) \times\left(\left[V_{\mathrm{t}}\right] / n\right)$, where $A_{\mathrm{x}}$ corresponds to the area measured for the $x$ vanadate species with $n$ as the oligomer number (number of vanadium atoms), $A_{\mathrm{t}}$ the sum of measured areas, and $\left[V_{\mathrm{t}}\right]$ the total vanadate concentration, according to that described elsewhere. ${ }^{14,29}$

\subsection{Measurements of F-actin stimulated S1- $\mathrm{Mg}^{2+}$-ATPase activity}

Actin samples $(2 \mu \mathrm{M})$ were incubated with various concentrations of meta-, decavanadate and sulfate vanadyl solutions at $25{ }^{\circ} \mathrm{C}$ for $20 \mathrm{~min}$, in $2 \mathrm{mM}$ Tris ( $\mathrm{pH} 7.5$ ), $0.2 \mathrm{mM} \mathrm{CaCl}_{2}$ and $0.2 \mathrm{mM}$ ATP. The stimulation of myosin S1 $\mathrm{Mg}^{2+}$-ATPase activity by F-actin was measured spectrophotometrically at $340 \mathrm{~nm}$ using the coupled enzyme pyruvate kinase/lactate dehydrogenase $(0.42 \mathrm{mM}$ 
phosphoenolpyruvate, $0.375 \mathrm{mM}$ NADH, $18 \mathrm{U}$ of lactate dehydrogenase, and $18 \mathrm{U}$ of pyruvate kinase), as in Tiago et al. ${ }^{9}$

\subsection{Measurements of cysteine oxidation}

The titration of actin cysteines was performed with DTNB, as indicated previously, ${ }^{30,31}$ using an extinction coefficient at $412 \mathrm{~nm}$ of $10900 \mathrm{M}^{-1} \mathrm{~cm}^{-1}$ for the coloured product thionitrophenolate. The assays were carried in $2 \mathrm{mM}$ Tris (pH 7.5), $0.2 \mathrm{mM} \mathrm{CaCl}_{2}$, in the presence or absence of $0.2 \mathrm{mM}$ ATP, after 20 min of incubation with meta- and decavanadate solutions.

\subsection{Electron paramagnetic resonance spectroscopy}

EPR spectra were carried out with a conventional X-band Bruker EMX 6/1 spectrometer equipped with a Bruker ER4116DM dual mode cavity. An Oxford ESR900 continuous-flow cryostat was used. The spectra of frozen solutions were acquired at $77 \mathrm{~K}$ using $0.2 \mathrm{ml}$ of samples with vanadyl sulfate and G- or F-actin in $2 \mathrm{mM}$ Tris (pH 7.5), $0.2 \mathrm{mM} \mathrm{CaCl}_{2} \pm 0.2 \mathrm{mM}$ ATP as desired. All the samples were prepared in a glove box and the solutions used were always purged with nitrogen before using. Therefore, after being prepared in anaerobic conditions, the samples were then closed and frozen with nitrogen when taken out from the glove chamber. Under these conditions, no oxidation is supposed to occur. NMR could be used to analyze the vanadate formation but the sensitivity is too low once $\mu \mathrm{M}$ concentrations of oxidovanadium(IV) were used. Besides, the presence of paramagnetic species broadens the NMR signals and decreases the signal/noise ratio. Upon titration of oxidovanadium(IV) with protein, the EPR intensities were determined from the transition peak of $-1 / 2$ perpendicular. Contrary to the studies performed in the glove chamber, the actin-vanadate reduction and subsequent oxidovanadium(IV) formation was evaluated using samples prepared in the same conditions of the cysteine oxidation measurements $(2 \mathrm{mM}$ Tris, $\mathrm{pH} 7.5,0.2 \mathrm{mM} \mathrm{CaCl} \pm 0.2 \mathrm{mM}$ ATP, incubation at $25^{\circ} \mathrm{C}$ for 20 min, aerobic conditions). Typical measurement conditions for CW-EPR were field modulation frequency, $100 \mathrm{kHz}$; modulation amplitude, $5 \mathrm{G}$; receiver gain, $2 \times 10^{5}$; time constant, $40.96 \mathrm{~ms}$; sweep time $167.77 \mathrm{~s}$; microwave power, $0.635 \mathrm{~mW}$ and the number of scans, 4. For the simulation of EPR spectra the linewidths for Gactin, were 20.0, 20.0, and $24.0 \mathrm{G}$, respectively for the $x$-direction, $y$-direction and $z$-direction whereas for F-actin: 22.2, 22.2 and 26.6 $\mathrm{G}$ were used. The lineshapes were Lorentzian/Gaussian for both.

\section{Results and discussion}

\subsection{Decavanadate stability, characterization and interaction with actin}

The decomposition of decameric vanadate species in the buffers used in the present study ( $2 \mathrm{mM}$ Tris, $\mathrm{pH} 7.5,0.2 \mathrm{mM} \mathrm{CaCl}_{2}$ plus $0.2 \mathrm{mM}$ ATP, wherever indicated), was monitored at $400 \mathrm{~nm}$, and followed a first-order kinetics (data not shown) in a temperaturedependent manner: the rate of decavanadate hydrolysis is considerably faster as the temperature is raised $\left(k_{25}{ }^{\circ} \mathrm{C}=0.129 \pm\right.$ $0.006 \mathrm{~h}^{-1}$ and $k_{45}{ }^{\circ} \mathrm{C}=0.769 \pm 0.023 \mathrm{~h}^{-1}$ ), in agreement with that described elsewhere. ${ }^{32,33}$ The presence of calcium or ATP in the concentrations used in the assays did not change the decavanadate rate of decomposition (data not shown). The activation energy,
$E_{\mathrm{a}}\left(\ln k=E_{\mathrm{a}} R^{-1} T^{-1}\right.$, where $k$ corresponds to the kinetic constant at temperature $T$, in Kelvin, and $R$ is the universal gas constant), is about $63.4 \pm 2.7 \mathrm{~kJ} \mathrm{~mol}^{-1}$ (Fig. 1). In other studies, in water and in $\mathrm{KCl} /$ imidazole buffer, the $E_{\text {a }}$ obtained was in the order of 94 and $97 \mathrm{~kJ} \mathrm{~mol}^{-1}$, respectively. ${ }^{32}$ The relatively high half-life time at $25^{\circ} \mathrm{C}(\approx 5.4 \mathrm{~h})$ and the type of kinetics allows the analysis of the interaction of decavanadate with actin even at relatively low total vanadate concentrations $(100 \mu \mathrm{M})$, that correspond to an even lower $(10 \mu \mathrm{M})$ decameric vanadate concentration.

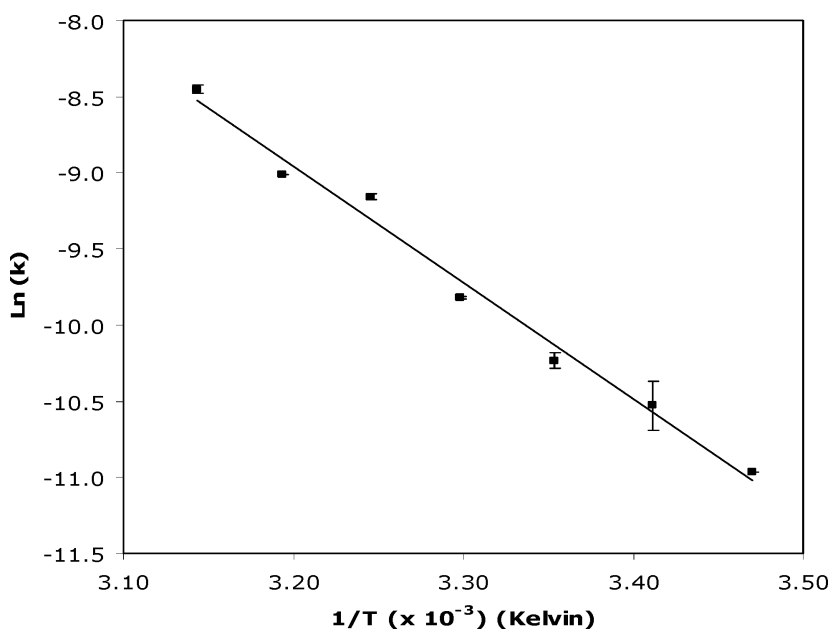

Fig. 1 Decomposition of decavanadate at $\mathrm{pH} 7.5$ and different temperature values. Decavanadate stock solution $(50 \mathrm{mM})$ was diluted to the final concentration ( $1 \mathrm{mM}$ total vanadate) at the start of the experiments in $2 \mathrm{mM}$ Tris, $\mathrm{pH} 7.5,0.2 \mathrm{mM} \mathrm{CaCl}_{2}, 0.2 \mathrm{mM}$ ATP. The first-order reactions were followed at $400 \mathrm{~nm}$ for $2 \mathrm{~h}$. Data (solid squares) are plotted as means \pm $\mathrm{SD}$. The results shown are the average of triplicate experiments.

As it has been described in previous studies, the ${ }^{51} \mathrm{~V}-\mathrm{NMR}$ spectroscopy of meta- and decavanadate solutions allows precise quantification of the amount of each vanadate species in the assays. ${ }^{14,15,29}$ In fact, for the decavanadate concentration used in the NMR studies ( $5 \mathrm{mM}$ total vanadate), the spectrum obtained (Fig. 2A) shows the characteristic signals of decameric $\left(\mathrm{V}_{10 \mathrm{~A}}\right.$ at $-516 \mathrm{ppm} ; \mathrm{V}_{10 \mathrm{~B}}$ at $-502 \mathrm{ppm} ; \mathrm{V}_{10 \mathrm{C}}$ at $\left.-424 \mathrm{ppm}\right)$ and monomeric species $\left(\mathrm{V}_{1}\right.$ at $\left.-561 \mathrm{ppm}\right)$, containing approximately $480 \mu \mathrm{M} \mathrm{V} V_{10}$ and $200 \mu \mathrm{M} \mathrm{V}_{1}$ (decameric vanadate is about 2.5-fold more concentrated than monomeric vanadate). Using NMR spectroscopy, it is possible to determine the decameric vanadate concentration, the presence of other vanadate oligomers in solution, as well as specific interactions with proteins. With total vanadate concentration in the $\mathrm{mM}$ range, $\mathrm{V}_{10}$ concentration increases linearly with total vanadate concentration. However this behaviour depends on vanadate oligomeric species. ${ }^{22}$ For instance, a metavanadate solution $(2 \mathrm{mM})$ contains $1 \mathrm{mM} \mathrm{V} \mathrm{V}_{1}(-561 \mathrm{ppm})$, $200 \mu \mathrm{M} \mathrm{V}_{2}(-567 \mathrm{ppm})$ and $120 \mu \mathrm{M} \mathrm{V}_{4}(-579 \mathrm{ppm})$, in equilibrium (Fig. 2B) and each of this species does not increase linearly with vanadate concentration, with the higher oligomers being favoured at higher vanadate concentrations.

The addition of G-actin $(40 \mu \mathrm{M})$ to a $5 \mathrm{mM}$ decavanadate solution (500 $\mu \mathrm{M}$ decameric species) has different effects on the signals of the vanadate species, promoting the half-height linewidth broadening of the decameric vanadate signal $\left(\mathrm{V}_{10 \mathrm{~A}}\right)$, from 139 to $299 \mathrm{~Hz}$ (2.1-fold), whereas its intensity (peak height) 


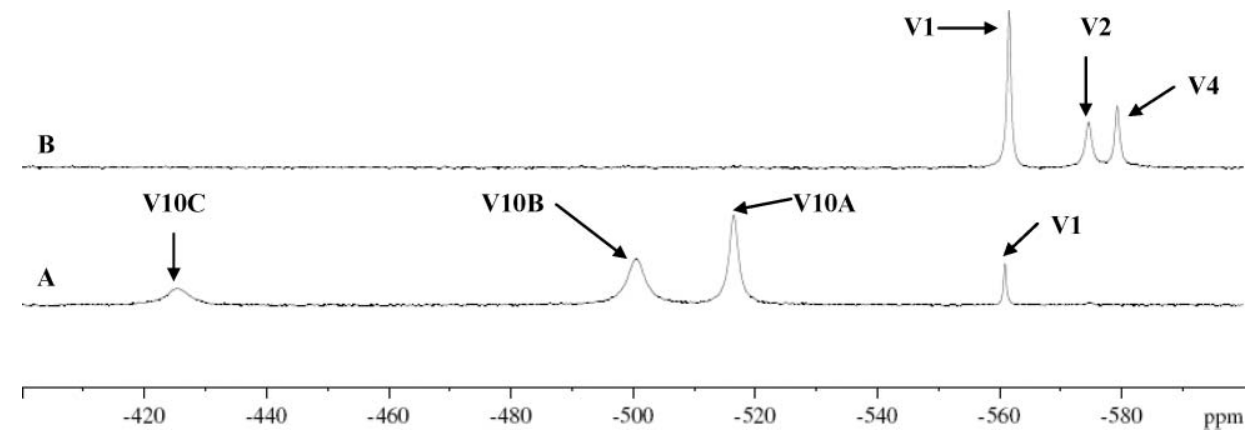

Fig. $2105.2 \mathrm{MHz}{ }^{51} \mathrm{~V}-\mathrm{NMR}$ spectra, at room temperature, of (A) $5 \mathrm{mM}$ decavanadate (total vanadate) and (B) $2 \mathrm{mM}$ metavanadate in $2 \mathrm{mM}$ Tris ( $\mathrm{pH}$ 7.5), $0.2 \mathrm{mM} \mathrm{CaCl}_{2} . \mathrm{V}_{1}$ and $\mathrm{V}_{2} \mathrm{NMR}$ signals correspond, respectively, to monomeric $\left(\mathrm{H}_{2} \mathrm{VO}_{4}{ }^{-}\right)$and dimeric $\left(\mathrm{HV}_{2} \mathrm{O}_{7}{ }^{3-}\right.$ and $\left.\mathrm{H}_{2} \mathrm{~V}_{2} \mathrm{O}_{7}{ }^{2-}\right)$ vanadate species irrespective of the protonation state, $\mathrm{V}_{4}$ and $\mathrm{V}_{5}$ correspond to cyclic tetrameric $\left(\mathrm{V}_{4} \mathrm{O}_{12}{ }^{4-}\right)$ and pentameric $\left(\mathrm{V}_{5} \mathrm{O}_{13}{ }^{5-}\right)$ vanadate species, whereas $\mathrm{V}_{10 \mathrm{~A}}$, $\mathrm{V}_{10 \mathrm{~B}}$ and $\mathrm{V}_{10 \mathrm{C}}$ signals correspond to the $\mathrm{V}(2), \mathrm{V}(1)$ and $\mathrm{V}(3)$ vanadium atoms in the decameric vanadate species $\left(\mathrm{V}_{10} \mathrm{O}_{28}{ }^{6-}\right)$.

decreases (Fig. 3A and B). Conversely, no significant changes were detected in the NMR signal corresponding to monomeric vanadate upon G-actin addition. By increasing the ionic strength (addition of $100 \mathrm{mM} \mathrm{KCl}$ ), a decrease in the half-height linewidth of $\mathrm{V}_{10 \mathrm{~A}}$ signals, from 299 to $219 \mathrm{~Hz}$ upon addition of protein was observed (1.5-fold), suggesting that the interaction between decameric vanadate and the protein is affected (Fig. 3C and D). Once the analysis of decameric vanadate versus $\mathrm{G}$-actin interaction is favoured at lower ionic strength, NMR studies were carried out without further addition of salts to the assays' medium (2 mM Tris, $\mathrm{pH} 7.5,0.2 \mathrm{mM} \mathrm{CaCl}$ ). In one of this set of experiments, it was observed that the presence of high concentrations of ATP $(5 \mathrm{mM})$ broadens the V10 signal (1.5-fold) (Fig. 3E and F).

Upon titration of decavanadate with G-actin, in the absence of any natural ligand (ATP), it was also observed that, at a 10:1 decavanadate ion:protein molecule ratio, the $\mathrm{V}_{10 \mathrm{~A}}$ signals did not present further broadening when the protein concentration increases (Fig. 4A). The G-actin concentration at which the broadening factor is halfway between bottom $(F=0.91 \pm 0.10)$ and top $(F=2.23 \pm 0.07)$ was $25.42 \pm 2.32 \mu \mathrm{M}$, taking into account the Boltzmann sigmoidal function used to fit the data (Fig. 4A).
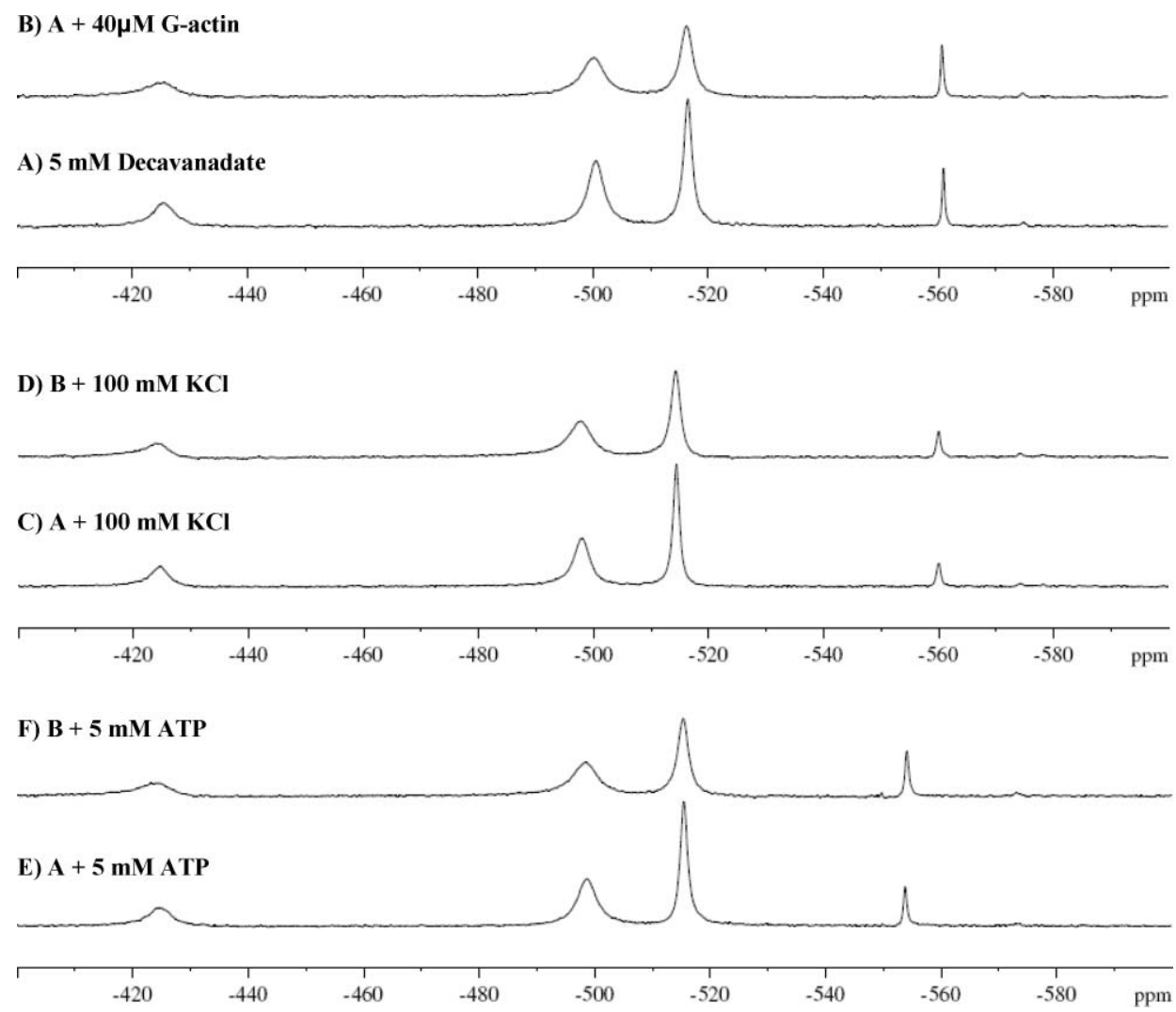

Fig. $3105.2 \mathrm{MHz}^{51} \mathrm{~V}$-NMR spectra, at room temperature, of $5 \mathrm{mM}$ decavanadate (total vanadate) in (A) $2 \mathrm{mM}$ Tris ( $\mathrm{pH}^{7.5}$ ), $2 \mathrm{mM} \mathrm{CaCl} \mathrm{m}_{2}$ and with (B) $40 \mu \mathrm{M}$ G-actin, (C) $100 \mathrm{mM} \mathrm{KCl}$, (D) solution C plus $40 \mu \mathrm{M}$ G-actin, (E) $5 \mathrm{mM}$ ATP, and (F) solution E plus $40 \mu \mathrm{M}$ G-actin. 
A

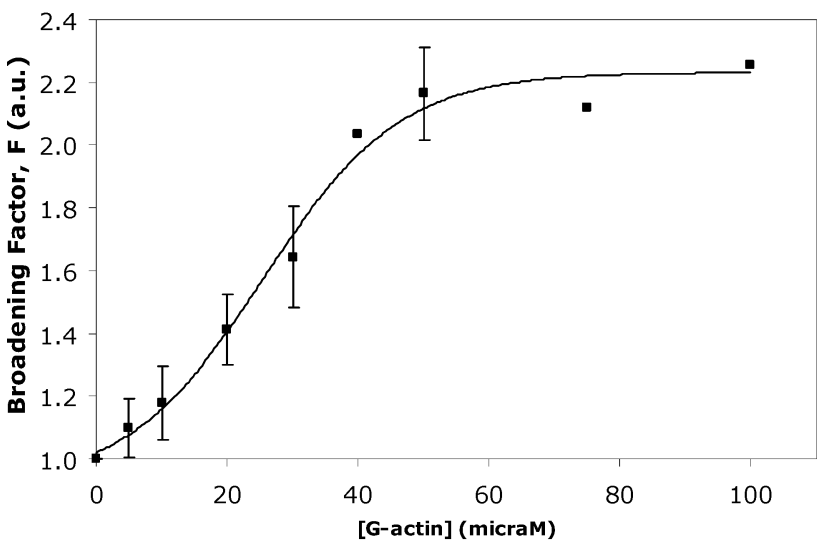

B

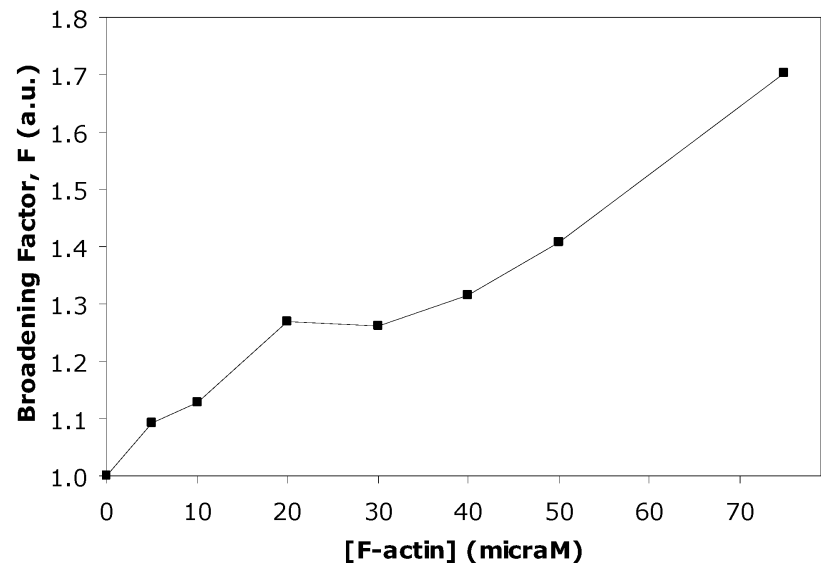

Fig. 4 Decavanadate solution (5 $\mathrm{mM}$ total vanadate) titrated with (A) G-actin in a medium containing $2 \mathrm{mM}$ Tris ( $\mathrm{pH}$ 7.5), $0.2 \mathrm{mM} \mathrm{CaCl}_{2}$; Data (solid squares) are plotted as means $\pm \mathrm{SD}$ and fitted with a Boltzmann sigmoidal function; and (B) F-actin in $2 \mathrm{mM}$ Tris (pH 7.5), $0.2 \mathrm{mM} \mathrm{CaCl}_{2}$, $0.2 \mathrm{mM}$ ATP. Broadening factor, $F$, represents the quotient between the line width of the $\mathrm{V}_{10 \mathrm{~A}}$ signal in the absence of actin and after protein addition. The results shown are the average of triplicate experiments. In certain experimental conditions the error bar is within the diameter of the symbol.

A similar experiment was conducted with the polymerized form of actin, but the dispersion pattern could not be fitted by any mathematical function and therefore no kinetic constants could be calculated (Fig. 4B). Note that in this graphic the error bars are within the diameter of the symbols. This low error of measurement, in comparison to the above situation with the monomeric form of actin, G-actin, is probably due to the viscosity of the polymerized form of actin. We also cannot exclude that the ratio between depolymerized/polymerized form of actin might be affected by the monomeric concentration of G-actin, that will contribute to a higher error of measurement of the width of the NMR signal observed in the former situation in particular for lower G-actin concentrations. Nevertheless, consistent with former studies, ${ }^{3,34}$ F-actin $(40 \mu \mathrm{M})$ produced a broadening from 165 to $207 \mathrm{~Hz}$ (1.3-fold) in the $\mathrm{V}_{10 \mathrm{~A}}$ NMR signal of the decameric vanadate species (data not shown).
Table $1 \mathrm{pH}$ effect in S1-ATPase $(0.05 \mathrm{mg} / \mathrm{ml})$ activity stimulated by $2 \mu \mathrm{M}$ F-actin treated with different decavanadate concentrations ([Decavanadate $]_{\text {stock }}=5 \mathrm{mM}$ ), in $2 \mathrm{mM} \mathrm{MES} \mathrm{(pH} \mathrm{6.0)} \mathrm{or} 2 \mathrm{mM}$ Tris (pH 7.5), $0.2 \mathrm{mM} \mathrm{CaCl}, 0.2 \mathrm{mM}$ ATP, $2.5 \mathrm{mM} \mathrm{MgCl}_{2}$, at $25^{\circ} \mathrm{C}$ for 20 min. Quantification by coupled enzymes assay. ${ }^{9}$ The results shown are the average of triplicate experiments

\begin{tabular}{lll}
\hline Buffer & $\mathrm{pH}$ & $\mathrm{IC}_{50}(\mu \mathrm{M})\left(\mathrm{V}_{10}\right)$ \\
\hline $2 \mathrm{mM}$ MES & 6.0 & $0.52 \pm 0.06$ \\
$2 \mathrm{mM}$ Tris & 7.5 & $0.80 \pm 0.15$ \\
\hline
\end{tabular}

\subsection{Decavanadate inhibits F-actin stimulated S1-ATPase activity}

Based on the above NMR observations, it is proposed that $\mathrm{V}_{10}$ NMR signals are affected upon actin interaction. This in turn leads to the question: is the actin function affected by this vanadate oligoanion? In order to clarify if decavanadate influences the actin physiological function, that is, the ability to stimulate the myosin ATPase activity during the process of muscle contraction, F-actin $(2 \mu \mathrm{M})$ was incubated with different vanadate, decavanadate and oxidovanadium(IV) concentrations and its subsequent capacity to stimulate myosin-S1-ATPase $(0.05 \mathrm{mg} / \mathrm{ml})$ activity was analyzed (Fig. 5). It was observed that while metavanadate and oxidovanadium(IV) solutions promote no more than $25 \%$ inhibition for the maximum vanadium concentration used $(50 \mu \mathrm{M})$, decavanadate, in turn, is a stronger inhibitor, preventing the ability of F-actin to stimulate S1-ATPase with an $\mathrm{IC}_{50}=8.04 \pm 1.49 \mu \mathrm{M}$ total vanadate, i.e. $0.80 \pm 0.15 \mu \mathrm{M}$ for decameric vanadate species. Since $\mathrm{HV}_{10} \mathrm{O}_{28}{ }^{5-}$ has a $\mathrm{p} K_{\mathrm{a}}$ value of 6.14 , the assays were also performed at pH 6.0 (2 mM MES, $0.2 \mathrm{mM} \mathrm{CaCl}, 0.2 \mathrm{mM} \mathrm{ATP})$ and an $\mathrm{IC}_{50}=$ $0.52 \pm 0.06 \mu \mathrm{M}$ for $\mathrm{V}_{10}$ was also determined (Table 1). Therefore, $\mathrm{HV}_{10} \mathrm{O}_{28}{ }^{5-}$ and $\mathrm{V}_{10} \mathrm{O}_{28}{ }^{6-}$ ions seem to have similar inhibitory effects in the actin stimulation of myosin ATPase activity.

\subsection{Actin cysteine oxidation versus decavanadate reduction}

If decameric vanadate affects the ability of actin to stimulate the myosin ATPase activity, this effect could be due to changes in the structure of actin that would be responsible for the blockage of myosin stimulation. On the other hand, decavanadate could affect the myosin ATPase activity itself. This second hypothesis has already been answered, since it was suggested that decameric vanadate behaves as a back-door myosin inhibitor. ${ }^{9,22}$ Regarding the changes in actin structure, it is known that disulfide bonds are important in the stabilization of protein structure and that thiol groups, located near the active center of enzymes for instance, are essential in the function of many enzymes. Therefore, since actin contains five cysteines that could react with vanadate, cysteine oxidation in the presence of vanadate was analyzed.

It was observed that after an exposure of 20 min to two different vanadate solutions, metavanadate and decavanadate, only the solution containing $\mathrm{V}_{10}$ was able to oxidize one of the G-actin core cysteine residues, with an $\mathrm{IC}_{50}=7.8 \pm 0.2 \mu \mathrm{M}$ decavanadate $(0.78 \mu \mathrm{M} \pm 0.02 \mathrm{~V} 10)$, while the only exposed residue (Cys$374)$, the so called "fast cysteine", remains in its reduced form (Fig. 6A). When ATP is present in the medium all five cysteine residues still maintain the reduced form (data not shown) upon exposure to decavanadate, suggesting that $\mathrm{V}_{10}$ interaction with actin is affected by ATP, as previously described using NMR spectroscopy. ${ }^{3}$ However, upon decavanadate incubation with 


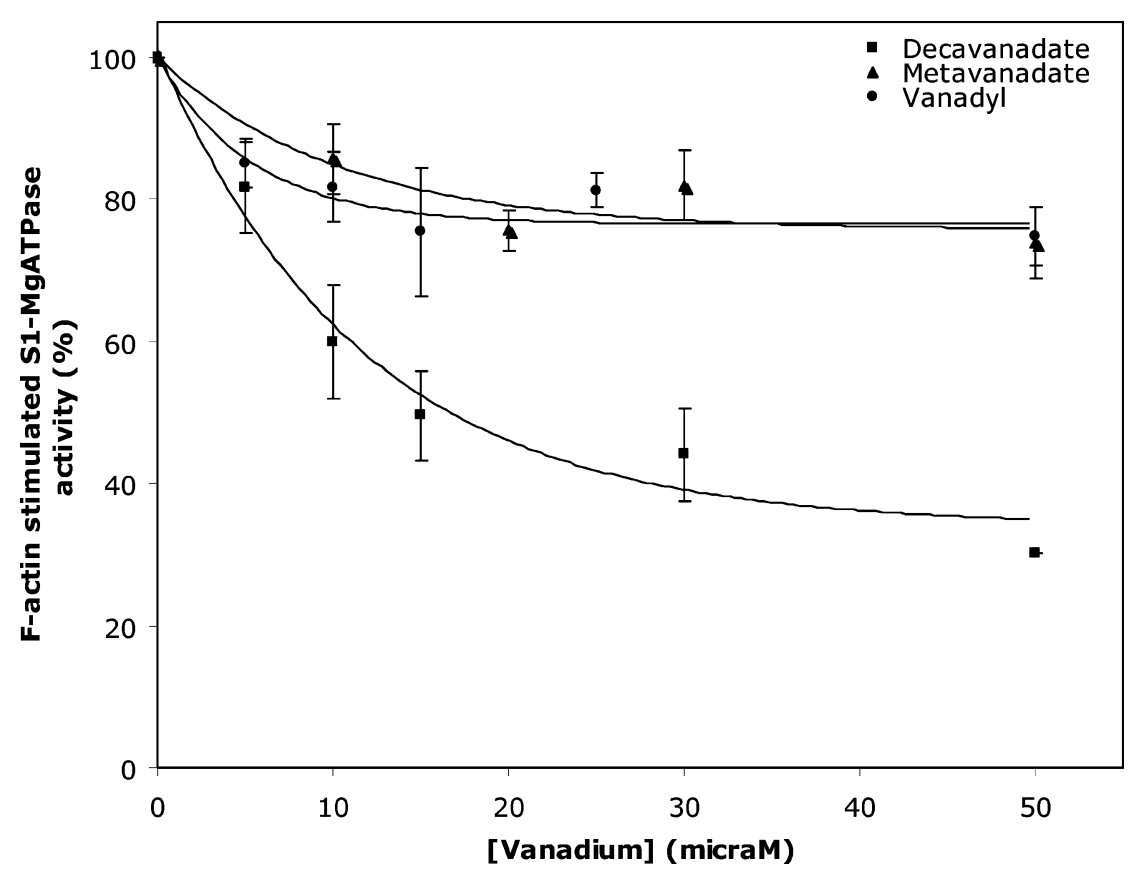

Fig. 5 Effect of F-actin incubation with V(IV) and V(V) on stimulation of S1 ATPase activity. F-actin $(2 \mu \mathrm{M})$ was incubated with different meta- (A), decavanadate $(\boldsymbol{\square})$ and vanadyl sulfate $(\bullet)$ concentrations for $20 \mathrm{~min}$ at $25^{\circ} \mathrm{C}$. The capacity to stimulate S1 ATPase $\left(0.05 \mathrm{mg} \mathrm{ml}{ }^{-1}\right)$ activity was monitored by coupled enzymes assay and followed at $340 \mathrm{~nm}$ as indicated in the Experimental section. Data (solid squares, triangles and circles) are plotted as means $\pm \mathrm{SD}$. The results shown are the average of triplicate experiments.

F-actin, full oxidation of the "fast cysteine" was observed, along with the oxidation of the core cysteine mentioned above, with $\mathrm{IC}_{50}$ values for vanadate-induced oxidation of exposed and total F-actin cysteines of $11.2 \pm 0.1$ and $20.9 \pm 0.2 \mu \mathrm{M}$ of decavanadate $\left(1.1\right.$ and $2.1 \mu \mathrm{M} \mathrm{V} \mathrm{V}_{10}$ ), respectively (Fig. $6 \mathrm{~B}$ and C). The Cys-374 oxidation upon decavanadate exposure may explain, at least in part, the observed blockage of myosin ATPase activity stimulation. Moreover, the oxidation of this residue may be involved in the F-actin depolymerization, as described elsewhere. ${ }^{35,36}$ Recently, it was pointed out that decavanadate prevents $\mathrm{G}$-actin polymerization with an $\mathrm{IC}_{50}$ of $17 \mu \mathrm{M} .{ }^{3}$ Once F-actin only promotes myosin ATPase stimulation, it is suggested that the effects promoted by decavanadate may involve changes in the structure of actin that alters the polymerization and the depolymerization process and therefore the stimulation of the enzyme activity.

When the incubation of decavanadate with actin was monitored by EPR, the addition of the decameric ion to the protein (25:1 decavanadate:protein ratio) elicited the appearance of a typical eight-band electron spin resonance spectrum assigned to oxidovanadium(IV), indicating vanadate reduction, probably through the above-mentioned reaction with sulfydryl groups of the protein (Fig. 7). Following the different G- and F-actin patterns for cysteine oxidation upon decavanadate incubation, the spectra demonstrate that significant differences exist between the local metal coordination environments for the oxidovanadium(IV) cation (Figs. 7B and C). Previously, the reaction of vanadate with thiol groups of fructose-1,6-bisphophate aldolase, ${ }^{37}$ and glyceraldehyde-3-P dehydrogenase was also described. ${ }^{38}$ On the other hand, it was noted that isocitrate dehydrogenase has the ability to reduce decavanadate. ${ }^{39}$ Although the presence of five cysteines in actin does not necessarily imply redox chemistry with vanadate, ${ }^{40}$ as was observed above, at specific protein conformation, that is when the actin is in the F-actin state, Cys-374 may react with vanadate, and be oxidized.

\subsection{Vanadyl interactions with actin}

The uptake of vanadate $(+5)$ by cells, namely erythrocytes, ${ }^{41}$ fat cells ${ }^{42}$ and yeast, ${ }^{43}$ is preceded by the rate-limiting reduction step to oxidovanadium(IV) ion, complexed with glutathione or proteins. ${ }^{38,40}$ Vanadate is also reduced in the presence of cysteines, generating cystine and oxidovanadium(IV),${ }^{44}$ with the sixth position of oxovanadium occupied by either carboxylateoxygen of two cysteine molecules. ${ }^{11}$

Although it was observed that the oxidovanadium(IV) cation only promotes a minor effect in F-actin-stimulated S1-ATPase activity, a parallel V(IV)-actin binding study was carried out by EPR at $77 \mathrm{~K}$, in order to reduce molecular motion. As can be observed in Fig. 8A, the addition of $250 \mu \mathrm{M} \mathrm{VOSO}_{4}$ to the reaction medium ( $2 \mathrm{mM}$ Tris, $0.2 \mathrm{mM} \mathrm{CaCl}$ ) did not promote the appearance of typical oxidovanadium(IV) signals. In fact, for $\mathrm{V}(\mathrm{IV})$ species, at physiological $\mathrm{pH}$ and in a non-complexing media, no EPR signal can be observed. For higher buffer concentrations ${ }^{13}$ it was observed that Tris interacts fairly strongly with the oxidovanadium(IV) cation $(20 \mathrm{mM}$ Tris and $0.001 \mathrm{M}$ $\left.\mathrm{VO}^{2+}\right)$. Thus the observation of an EPR spectrum at neutral $\mathrm{pH}$ would indicate that either a complexing ligand is present in solution or that the $\mathrm{pH}$ is no longer neutral. ${ }^{5,45}$ Since no alterations in $\mathrm{pH}$ value (7.5) were observed subsequent to oxidovanadium(IV) addition to the reaction mixture, immediately before samples were frozen with liquid nitrogen, the signals observed upon G- and F-actin addition (50 and $30 \mu \mathrm{M}$, respectively) can only be attributed to a metal-protein interaction (Fig. 8B and C, respectively). 
A
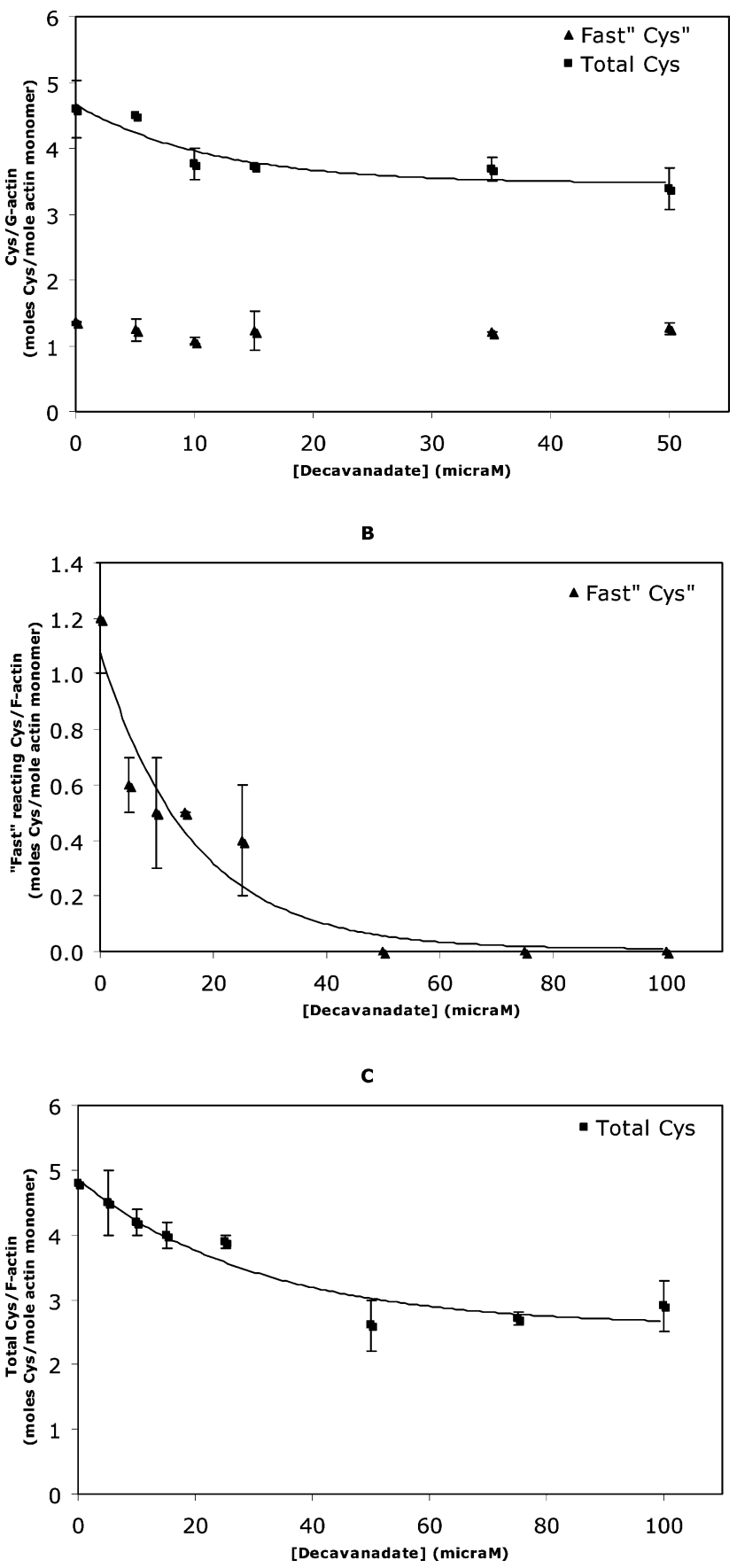

Fig. 6 G- (A) and F-actin (B, C) cysteine oxidation upon treatment of actin with decavanadate. Titration of cysteines was performed with $0.1 \mathrm{mM}$ DTNB and $2 \mu \mathrm{M}$ actin in $2 \mathrm{mM}$ Tris $(\mathrm{pH} 7.5), 0.2 \mathrm{mM}$ $\mathrm{CaCl}_{2}$ (G-actin) and $0.2 \mathrm{mM} \mathrm{ATP} \mathrm{(F-actin).} \mathrm{The} \mathrm{increase} \mathrm{in} \mathrm{absorbance}$ at $412 \mathrm{~nm}$ was continuously recorded over $10 \mathrm{~min}$; to measure total cysteines the samples were treated afterwards with $1 \%$ SDS and the absorbance was measured over 15-30 min until a steady value was reached. (A) Treatment with decavanadate produced a dose-dependent decrease of G-actin total cysteines ( $\square$ ) while Cys-374 remained in the reduced form $(\mathbf{A})$. (B) Treatment with decavanadate produced a complete dose-dependent decrease of exposed F-actin cysteine ( $\mathbf{A}$ ). (C) Treatment with decavanadate produced a dose-dependent decrease of total F-actin cysteines ( $\mathbf{\square}$ ). Data (solid squares and triangles) are plotted as means \pm $\mathrm{SD}$. The results shown are the average of triplicate experiments.

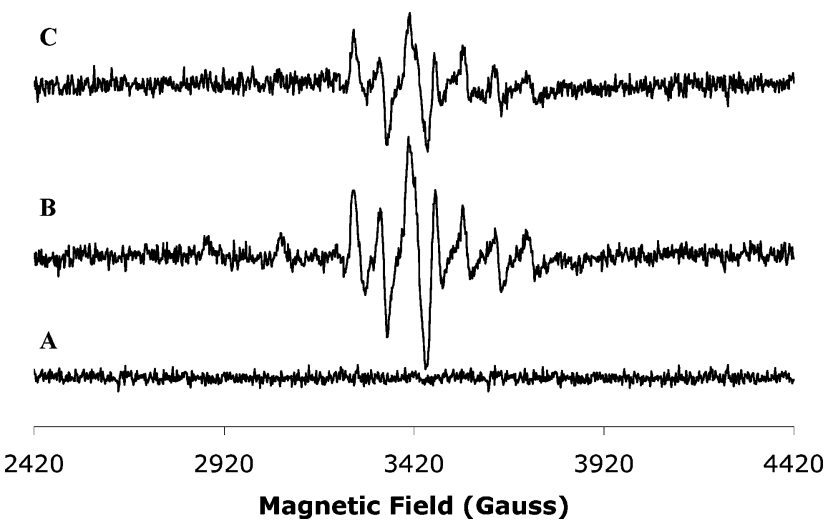

Fig. 7 Frozen aqueous solution X-band EPR spectra of $25 \mathrm{mM}$ decavanadate (vanadate total) in (A) $2 \mathrm{mM}$ Tris (pH 7.5), $0.2 \mathrm{mM} \mathrm{CaCl}_{2}$, $0.2 \mathrm{mM}$ ATP with (B) $100 \mu \mathrm{M}$ G-actin or (C) $100 \mu \mathrm{M}$ F-actin. Upon protein addition the oxidovanadium(IV) typical signals are elicited.

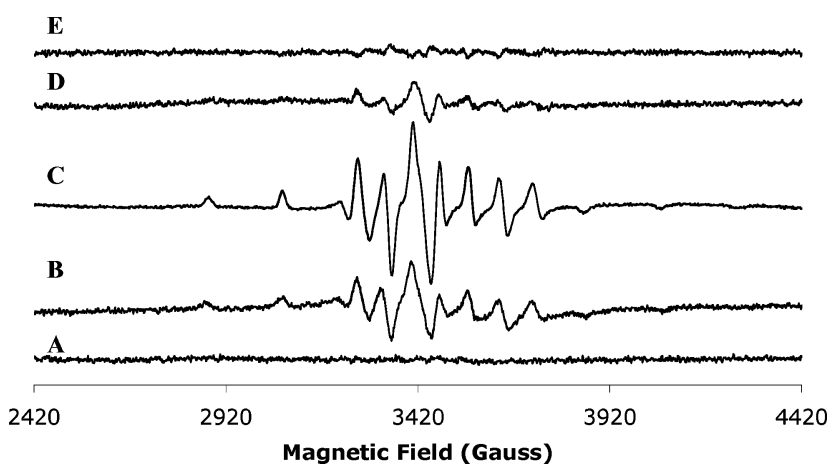

Fig. 8 Frozen aqueous solution X-band EPR spectra of $250 \mu \mathrm{M} \mathrm{VOSO}$ in (A) $2 \mathrm{mM}$ Tris (pH 7.5), $0.2 \mathrm{mM} \mathrm{CaCl}$, with (B) $50 \mu \mathrm{M}$ G-actin, (C) $30 \mu \mathrm{M}$ F-actin, (D) $0.2 \mathrm{mM}$ ATP and (E) $50 \mu \mathrm{M}$ G-actin plus $0.2 \mathrm{mM}$ ATP.

Therefore, the absolute intensity of the vanadium EPR signals can be correlated upon titration of oxidovanadium(IV) with protein. ${ }^{46}$ Upon ATP addition, a complex between oxidovanadium(IV) cation and nucleotide occurs ${ }^{47}$ (Fig. 8D); thus when the buffer assay contains ATP ( $2 \mathrm{mM}$ Tris, $0.2 \mathrm{mM} \mathrm{CaCl}_{2}, 0.2 \mathrm{mM}$ ATP) the $\mathrm{VO}^{2+}-\mathrm{ATP}$ complex can be observed in the EPR spectra. Moreover, it was observed that the presence of ATP in the medium prevents the interaction between oxidovanadium(IV) ion and G-actin, since the EPR signals almost disappear, being less intense when the nucleotide is concomitantly added to the assay (Fig. 8E). Although all the samples were prepared in the same conditions in the glove chamber, the reduction of the EPR signal, in the case of paramagnetic ions, could be due to either spin-spin interactions between the $\mathrm{VO}^{2+}$ and the added nucleotide or from the displacement of $\mathrm{VO}^{2+}$ from the protein. The reduction of the EPR intensity could also arise from partial metal ion re-oxidation.

Based on the experimental hyperfine constant, $A_{\|}$, it is possible to predict the contribution of the donors to this value, that is, the nuclei to which the unpaired electrons are coupled. However, as the typical $A_{\|}$values obtained by simulation varies between $31.9 \times$ $10^{-4}$ and $45.7 \times 10^{-4} \mathrm{~cm}^{-1}$, with the generally accepted error being ca. $\pm 1.5 \times 10^{-4}$, the use of the additivity relationship introduces a caveat since there is often more than one combination of ligands which can, within the error limits, give the experimentally 
determined $A_{\|}$. Therefore, more than one combination of donors, can give the observed value $(195.6 \mathrm{G})$, the possibility of a species of three water molecules and one carboxylate (Asp or Glu), or one imidazole (His) or of species with two waters and two imidazoles (or their combination) must be taken into account. As a consequence, the knowledge of the possible ligand types in the protein (or in any other molecules) structure is of primary importance. ${ }^{48}$ As a simulation spectrum of the interaction between oxidovanadium(IV) and F-actin presents $A_{\|}=195.6 \mathrm{G}=$ $531.0798 \mathrm{MHz}, A_{\perp}=65 \mathrm{G}, g_{\perp}=1.998$ and $g_{\|}=1.9399$ (Fig. 9, top), it is suggested that the oxidovanadium(IV) ion is coordinated to the oxygen of three water molecules and one equatorial nitrogen of an amine group present in the lateral amino acid residue chain such as asparagine (Asn), glutamine (Gln) or lysine (Lys), taking into account the $A_{\|}$and the $g_{\|}$values obtained and the table of the equatorial vanadyl ligands from Chasteen. ${ }^{49}$ Since it is known that Lys-336 is close to the nucleotide ring in the tertiary structure of actin, ${ }^{50}$ the above results with ATP and G-actin indicate that the oxidovanadium(IV) ion may be bound to the nitrogen of the Lys-336's side chain. When actin is in its polymerized form the nucleotide binding pocket is eventually blocked and ATP presence does not alter the V(IV)-F-actin spectrum.
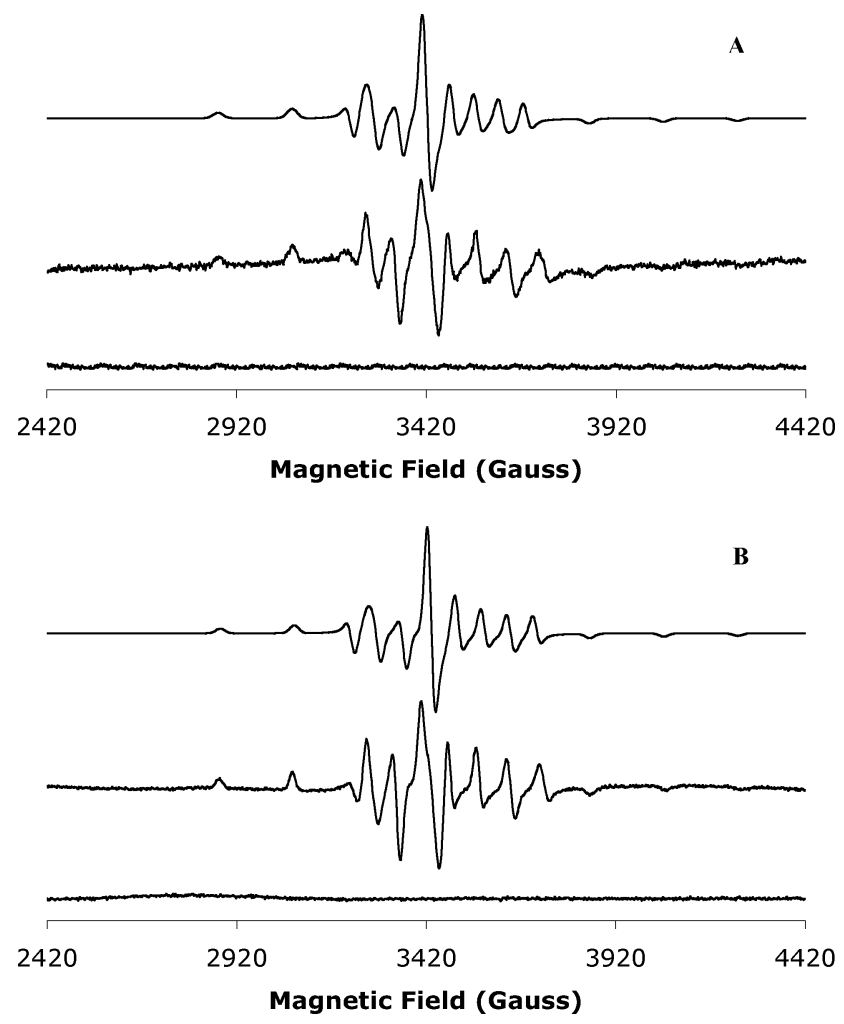

Fig. 9 Frozen aqueous solution X-band EPR spectra of VO-actin. $\mathrm{VOSO}_{4}$ concentration was $250 \mu \mathrm{M}$. The protein concentrations were (A) $30 \mu \mathrm{M}$ F-actin, in $2 \mathrm{mM}$ Tris (pH 7.5), $0.2 \mathrm{mM} \mathrm{CaCl}_{2}, 0.2 \mathrm{mM}$ ATP; and (B) $50 \mu \mathrm{M}$ G-actin, in $2 \mathrm{mM}$ Tris (pH 7.5), $0.2 \mathrm{mM} \mathrm{CaCl}_{2}$. The bottom traces in (A) and (B) are the spectra in the absence of protein. The middle spectra are the experimental spectra of the preparations with actin added. The top spectra are the corresponding spectra simulation with the EPR parameters given in the text. For the simulation of EPR spectra the linewidths for G-actin, were 20.0, 20.0, and 24.0 G, respectively for the $x$-direction, $y$-direction and $z$-direction whereas for F-actin: 22.2, 22.2 and $26.6 \mathrm{G}$ were used. The lineshapes were Lorentzian/Gaussian for both.
The extent of $\mathrm{VO}^{2+}$ binding to actin was measured from the $m_{\mathrm{i}}=-1 / 2$ perpendicular line, (Fig. 9), since this band exhibits the major intensity and the best linearity when oxidovanadium(IV) $(250 \mu \mathrm{M})$ is titrated with actin (data not shown). The intensity of this band was plotted against oxidovanadium(IV) concentration $(\mu \mathrm{M})$ and $K_{\mathrm{d}}$ of $7.48 \pm 1.11 \mu \mathrm{M}$ G-actin and $43.05 \pm 5.34 \mu \mathrm{M}$ F-actin (Fig. 10A and B) was calculated. From the data collected in latter plots, it was determined that aproximately 1 and $4 \mathrm{VO}^{2+}$ ions are bound per G- and F-actin molecule, respectively. Other studies performed with ferritin described a stoichiometry of 16 $\mathrm{VO}^{2+}$ per protein. ${ }^{45}$ Therefore, the observed decrease in EPR signal intensities of the $\mathrm{VO}^{2+}-\mathrm{G}$-actin spectrum by comparison with $\mathrm{VO}^{2+}-\mathrm{F}$-actin, can be explained by the $\mathrm{VO}^{2+}$ cation bound to the monomeric state of the protein.
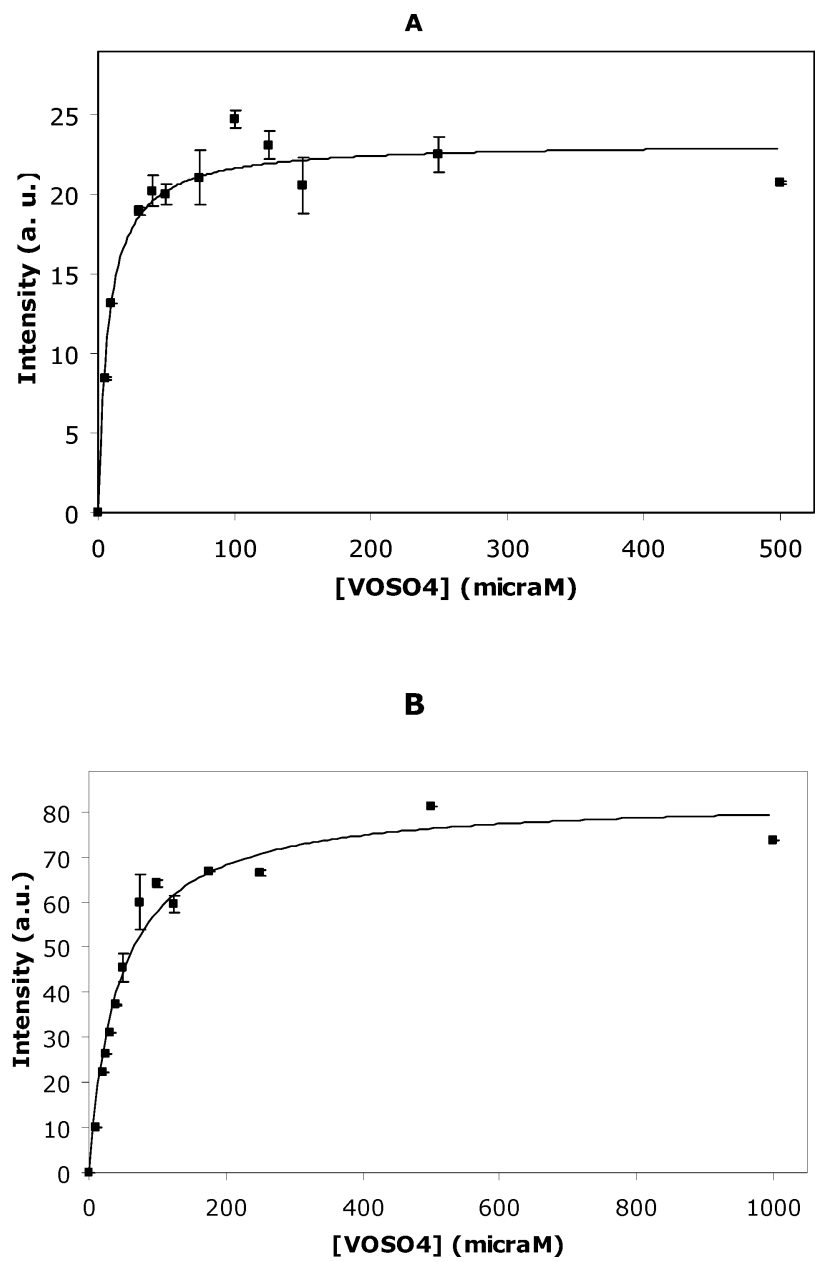

Fig. 10 EPR intensities from the transition peak $m_{\mathrm{i}}=-1 / 2$ perpendicular line of $250 \mu \mathrm{M} \mathrm{VOSO}_{4}$ titrated with different concentrations of (A) G-actin, in $2 \mathrm{mM}$ Tris (pH 7.5), $0.2 \mathrm{mM} \mathrm{CaCl}_{2}$; and (B) F-actin, in $2 \mathrm{mM}$ Tris (pH 7.5), $0.2 \mathrm{mM} \mathrm{CaCl}_{2}, 0.2 \mathrm{mM}$ ATP. Data (solid squares) are plotted as means $\pm \mathrm{SD}$. The results shown are the average of triplicate experiments.

Since oxidovanadium(IV) has little effect on the S1-ATPase activity stimulated by F-actin, although strong evidence of binding to actin have been observed, it could be predicted that oxidovanadium(IV) binds to actin in places that do not significantly alter the actin conformation and its ability to interact with the myosinsubfragment-1. 


\section{Conclusions}

Knowledge of mechanisms of action of vanadium in processes that involve actin is scarce or nonexistent. So far, in cells, vanadate is known to stabilize F-actin filaments through the formation of F-actin-ADP. $V_{1}$ complexes and induces actin polymerization by inhibiting specific tyrosine phosphatases, whereas in vitro, decavanadate is particularly involved in the inhibition of both actin polymerization and myosin ATPase activity. In the present paper, it is suggested that decavanadate interaction with F-actin induces oxidation of cysteine through a process that involves the reduction of vanadate to oxidovanadium(IV). It is proposed that changes in protein structure due to cysteine oxidation may be responsible, at least in part, for the inhibition of myosin ATPase activity stimulated by F-actin.

It was concluded that the decomposition of $\mathrm{V}_{10}$ follows a first order kinetic in a temperature-dependent manner and with an $E_{\text {a }}$ of $63.4 \pm 2.7 \mathrm{~kJ} \mathrm{~mol}^{-1}{ }^{1}$ Using NMR spectroscopy, it was possible to analyze the vanadate species and the composition of the vanadate solutions at several experimental conditions, as well as the specific interactions of the different vanadate oligomers with the protein. It was observed that interaction of actin with $\mathrm{V}_{10}$, as analysed by the broadening of the $\mathrm{V}_{10 \mathrm{~A}} \mathrm{NMR}$ signal, decreases upon increasing ionic strength and increases in the presence of high concentrations of ATP, a natural ligand of the protein. The broadening factor of $\mathrm{V}_{10 \mathrm{~A}} \mathrm{NMR}$ signal increases as a sigmoid function upon increasing G-actin concentration whereas no similar pattern was observed upon titration with F-actin. For G-actin, a $2.5 \mu \mathrm{M}$ concentration of $\mathrm{V}_{10}$ species is enough to produce $50 \%$ of the broadening effect. By comparison to vanadate or oxidovanadium(IV), decavanadate inhibits strongly the myosin ATPase activity stimulated by F-actin, with an $\mathrm{IC}_{50}$ of $0.8 \mu \mathrm{M} \mathrm{V}_{10}$ species. Decavanadate, but not metavanadate, incubation with Factin induces Cys-374 oxidation, the so called "fast cysteine", with a $\mathrm{IC}_{50}$ of $1 \mu \mathrm{M} \mathrm{V} \mathrm{V}_{10}$ species besides the oxidation of a core cysteine, whereas for G-actin only the latter effect is observed. Actin exposure to decavanadate promotes vanadate reduction, since a typical EPR signal is detected. Following $\mathrm{V}_{10}$ reduction to oxidovanadium(IV), it is suggested that the cation may form a complex with $\mathrm{G}$-actin and $\mathrm{F}$-actin with 1:1 and 4:1 stoichiometries, respectively. The interaction of oxidovanadium(IV) ion may occur close to the ATP binding site since our observations suggest coordination to Lys-336 and 3 water molecules. Although further studies will be needed, it is believed that the present data will contribute to the understanding of the role of vanadium in biochemical processes where actin is present.

\section{Acknowledgements}

S. R. would like to thank Fundação para a Ciência e TecnologiaMCTES for the PhD grant (SFRH/BD/29712/2006).

\section{References}

1 M. Aureliano and D. C. Crans, J. Inorg. Biochem., 2009, 103, 536-546.

2 M. Aureliano, in Vanadium Biochemistry, ed M. Aureliano, Research Signpost Publishers, Kerala, India, 2007.

3 S. Ramos, M. Manuel, T. Tiago, R. M. C. Gândara, J. Martins, R. O. Duarte, J. J. G. Moura, C. Gutiérrez-Merino and M. Aureliano, J. Inorg. Biochem., 2006, 100, 1734-1743.
4 N. D. Chasteen, in Structure and Bonding, ed. M. J. Clarke, J. B. Goodenough, J. A. Ibers, C. K. Jørgensen, D. M. P. Mingos, J. B. Neilands, G. A. Palmer, D. Reinen, P. J. Sadler, R. Weiss and R. J. P. Williams, Springer-Verlag, New York, 1983, vol. 53, pp. 105-138.

5 D. C. Crans, J. J. Smee, E. Gaidamauskas and L. Yang, Chem. Rev, 2004, 104, 849 .

6 L. Petterson, B. Hedman, I. Andersson and N. Ingri, Chem. Scr., 1983, 22, 254.

7 L. Petersson, I. Andersson and B. Hedman, Chem. Scr., 1985, 25, 309.

8 D. C. Crans, Comments Inorg. Chem., 1993, 16, 1.

9 T. Tiago, M. Aureliano and C. Gutierrez-Merino, Biochemistry, 2004, 43, 5551 .

10 D. Rehder, BioMetals, 1992, 5, 3.

11 H. Sakurai and S. Shimomura, Inorg. Chim. Acta, 1981, 55, L67.

12 I. Khan, Q. Chen, D. P. Goshorn and J. Zubieta, Inorg. Chem., 1993, 32, 672-680.

13 D. C. Crans, R. L. Bunch and L. A. Theisen, J. Am. Chem. Soc., 1989, 111, 7597.

14 M. Aureliano and V. M. C. Madeira, Biochim. Biophys. Acta, Mol. Cell Res., 1994, 1221, 259-271.

15 D. C. Crans, E. M. Willging and S. R. Butler, J. Am. Chem. Soc., 1990, $112,427$.

16 J. A. Saponja and H. J. Vogel, J. Inorg. Biochem., 1996, 62, 253.

17 D. Rehder, H. Holst, R. Quass, W. Hinrichs, U. Hahn and W. Saenger, J. Inorg. Biochem., 1989, 37, 141.

18 I. Bougie and M. Bisaillon, Biochem. J., 2006, 398, 557-567.

19 B. Nilius, J. Prenen, A. Janssens, T. Voets and G. Droogmans, J. Physiol., 2004, 560, 753-765.

20 S. S. Soares, C. Gutiérrez-Merino and M. Aureliano, J. Inorg. Biochem., 2007, 101, 789-796.

21 K. Fohr, J. Scott, G. Ahnert-Hilger and M. Gratzl, Biochem. J., 1989, 262, 83-89.

22 T. Tiago, P. Martel, C. Gutiérrez-Merino and M. Aureliano, Biochem. Biophys. Acta, 2007, 1771, 474-480.

23 L. C. Cantley Jr., L. Josephson, R. Warner, M. Yanagisawa, C. Lechene, G. Guidotti, J. Biol. Chem. 1977, 252, 7421-7423.

24 M. Aureliano, F. Henao, T. Tiago, R. O. Duarte, J. J. G. Moura, B. Baruah and D. C. Crans, Inorg. Chem., 2008, 47, 5677-5684.

25 C. Combeau and M.-F. Carlier, J. Biol. Chem., 1988, 263, 17429.

26 E. Brener, S. Rubinstein, G. Cohen, K. Shternall, J. Rivlin and H. Breitbart, Biol. Reprod., 2003, 68, 837-845.

27 J. D. Pardee and J. A. Spudich, Methods Enzymol., 1982, 85, 164.

28 D. J. Gordon, Y. Z. Yang and E. D. Korn, J. Biol. Chem., 1976, 251, 7474.

29 S. S. Soares, H. Martins, J. Coucelo, C. Gutiérrez-Merino and M. Aureliano, J. Inorg. Biochem., 2007, 101, 80-88.

30 C. Gutierrez-Merino, Arch. Biochem. Biophys., 1987, 252, 303.

31 Y. Gutierrez-Martin, F. J. Martin-Romero, F. A. Inesta-Vaquera, C. Gutierrez-Merino and F. Henao, Eur. J. Biochem., 2004, 271, 2647.

32 P. Csermely, A. Martonosi, G. C. Levi and A. J. Ejchart, Biochem. J., 1985, 230, 807.

33 S. Varga, P. Csermely and A. Martonosi, Eur. J. Biochem., 1985, 148, 119.

34 T. Tiago, M. Aureliano and J. J. G. Moura, J. Inorg. Biochem., 2004, 98, 1902.

35 A. Milzani, R. Rossi, P. Di Simplicio, D. Giustarini, R. Colombo and I. Dalle-Donne, Protein Sci., 2000, 9, 1774.

36 I. Dalle-Donne, R. Rossi, D. Giustarini, N. Gagliano, L. Lusini, A. Milzani, P. Di Simplicio and R. Colombo, Free Radical Biol. Med., 2001, 31, 1075-1083.

37 D. C. Crans, K. Sudhakar and T. J. Zamborelli, Biochemistry, 1992, 31, 6812.

38 J. E. Benabe, L. A. Echegoyen, B. Pastrana and M. MartínezMaldonado, J. Biol. Chem., 1987, 262, 9555.

39 A. V. S. Rao and T. Ramasarma, Biochem. Biophys. Acta, 2000, 1474, 321.

40 D. C. Crans and C. M. Simone, Biochemistry, 1991, 30, 6734.

41 I. G. Macara, K. Kustin and L. C. Jr. Cantley, Biochem. Biophys. Acta, 1980, 629, 95 . 
42 H. Degani, M. Gochlin, S. J. Karlish and Y. Schechter, Biochemistry, 1981, 20, 5795 .

43 G. R. Willsky, D. A White and B. C. McCabe, J. Biol. Chem., 1984, 259, 13273-13281.

44 K. Kustin and D. L. Toppen, Inorg. Chem., 1973, 12, 1404 1407.

45 N. D. Chasteen and E. C. Theil, J. Biol. Chem., 1982, 257, 7672.
46 K. Fukui, T. Ueki, H. Ohya and H. Michibata, J. Am. Chem. Soc., $2003,125,6352$

47 N. Katsaros, Transition Met. Chem., 1982, 7, 72.

48 T. S. Smith II, R. LoBrutto and V. C. Pecoraro, Coord. Chem. Rev., 2002, 228, 1.

49 N. D. Chasteen, in, Biological Magnetic Resonance, ed. L. Berhiner and J. Reuben, 1981, Plenum Press, New York, pp. 53-119.

50 G. Hegyi, L. Szilagyi and M. Elzinga, Biochemistry, 1986, 25, 5793. 